\title{
Cloning and expression of an $\alpha$-amylase gene from Streptomyces thermoviolaceus CUB74 in Escherichia coli JM107 and S. lividans TK24
}

\author{
SAMI M. BAHRI* and JOHN M. WARD \\ Biochemistry Department, University College London, Gower Street, London WCIE 6BT, UK
}

(Received 7 August 1989; revised 14 November 1989; accepted 15 January 1990)

\begin{abstract}
A gene coding for a thermostable extracellular $\alpha$-amylase, carried by a $5.7 \mathrm{~kb}$ BamHI chromosomal DNA fragment isolated from Streptomyces thermoviolaceus strain CUB74, was cloned into Escherichia coli JM107 using, as a cloning vector, the high-copy-number plasmid pUC8. E. coli containing a recombinant plasmid pQR300 expressed the amylase gene and exported the enzyme into the periplasmic space and the culture medium. The amylase protein expressed by $E$. coli had the same molecular mass $(50 \mathrm{kDa})$ as that expressed by the Streptomyces parent strain, which suggests that the enzyme is processed similarly by both strains. The amylase gene was also cloned into Streptomyces lividans $\mathrm{TK} 24$ using $\mathrm{pIJ702}$ as vector. The enzyme was stable at $70{ }^{\circ} \mathrm{C}$ when $\mathrm{CaCl}_{2}$ was present.
\end{abstract}

\section{Introduction}

$\alpha$-Amylases are secreted endoenzymes that randomly cleave $\alpha(1,4)$ linkages in starch, generating shorter chains of glucose units which can eventually be taken up and utilized by many organisms. $\alpha$-Amylase is found widely amongst Streptomyces species. Recently, $\alpha$-amylases have been isolated and characterized from Streptomyces hygroscopicus, $S$. venezuelae, and $S$. limosus. S. hygroscopicus $\mathrm{SF}-1084$ produces an extracellular $\alpha$-amylase which is used industrially to hydrolyse starch to maltose. The gene specifying the enzyme has been isolated and sequenced (Hoshiko et al., 1987; McKillop et al., 1986). The amylase gene of $S$. limosus has also been isolated and sequenced. Its amino acid sequence showed regions with up to $80 \%$ homology to mammalian and invertebrate $\alpha$ amylases (Long et al., 1987) but not to other bacterial, fungal or plant $\alpha$-amylases. The gene for an $\alpha$-amylase from $S$. venezuelae has recently been cloned and characterized (Virolle et al., 1988). The predicted amino acid sequence of this enzyme shows $75 \%$ identity with the $S$. limosus $\alpha$-amylase.

High hydrolysis temperatures are desirable in the starch industry because starch granules cannot be attacked by $\alpha$-amylase unless they have been ruptured by heat (gelatinization). Since the enzymes of thermophilic bacteria are generally heat-stable (Ljungdahl, 1979), we are investigating amylases produced by thermophilic Streptomyces strains.
Cloning and expression of Streptomyces genes have been mostly carried out within Streptomyces (Bibb et al., 1983). However, a few examples of expression of cloned Streptomyces genes in Escherichia coli have been reported. These include genes for antibiotic resistance (e.g. Vara et al., 1985; Gil et al., 1985; Schupp et al., 1983), a gene for an extracellular endoglycosidase $\mathrm{H}$ (Robbins $e t$ al., 1981), and a few examples of genes for biosynthetic enzymes (Meade, 1985; Hercomb et al., 1987).

In this paper, we report the isolation of an $\alpha$-amylase gene from a thermophilic streptomycete, $S$. thermoviolaceus strain CUB74, and its cloning and expression in $E$. coli and $S$. lividans.

\section{Methods}

Bacterial strains and plasmids. The characteristics of E. coli JM107 and S. lividans TK 24 are shown in Table 1. S. thermoviolaceus strain CUB74 was obtained from Dr A. McCarthy (University of Liverpool, UK). Plasmids pUC8, 18 and 19 were used for cloning in $E$. coli whereas pQR1 (R. Barallon \& J. M. Ward, unpublished) and pIJ903 (Lydiate et al., 1985) were used as shuttle vectors for cloning in both $E$. coli and Streptomyces strains. $\mathrm{pQR} 1$ was constructed by ligating pBR325 and pIJ702 that had been digested with PstI. pIJ702 was also used for cloning in $S$. lividans.

Culture media and antibiotics. E. coli strains were grown at $37^{\circ} \mathrm{C}$ in nutrient broth (Oxoid) or on nutrient agar (Oxoid nutrient broth solidified with $2 \%, \mathrm{w} / \mathrm{v}$; Difco agar); both media were supplemented with ampicillin $\left(500 \mu \mathrm{g} \mathrm{ml}^{-1}\right)$, IPTG $\left(40 \mu \mathrm{g} \mathrm{ml}^{-1}\right)$, X-gal $\left(80 \mu \mathrm{g} \mathrm{ml}^{-1}\right)$ and potato starch $(1 \%, \mathrm{w} / \mathrm{v}$; Sigma, type S-4251) when necessary. $S$. 
Table 1. Bacteria and plasmids

\begin{tabular}{|c|c|c|}
\hline $\begin{array}{l}\text { Bacterial strain } \\
\text { or plasmid }\end{array}$ & $\begin{array}{l}\text { Genotype or } \\
\text { relevant characteristics }\end{array}$ & Reference \\
\hline E. coli JM107 & $\begin{array}{l}\text { endAl gyrA96 thi-1 hsdRI7 } \\
\text { supE44 relAl } \triangle(\text { lac-proAB }) \\
\left(\mathrm{F}^{\prime} \text { traD36, proAB, }\right. \\
\left.\text { lacI } I^{\natural} \mathrm{Z} \triangle \mathrm{M} 15\right)\end{array}$ & Yanisch-Perron et al. (1985) \\
\hline S. lividans TK24 & Str-6, SLP2- SLP3- & Hopwood et al. (1983) \\
\hline $\begin{array}{l}\text { pUC8, pUC18, pUC19 } \\
\text { pQR1 }\end{array}$ & $\begin{array}{l}\mathrm{Ap}^{\mathrm{r}}, \text { lac } Z \alpha \\
\mathrm{pIJ} 702 / \mathrm{pBR} 325 \text { hybrid; } \mathrm{Ts}^{\mathrm{r}} \\
\mathrm{Cm}^{\mathrm{r}} \mathrm{Tc}^{\mathrm{r}}\end{array}$ & $\begin{array}{l}\text { Vieira \& Messing (1982) } \\
\text { R. Barallon \& J. M. Ward, } \\
\text { unpublished }\end{array}$ \\
\hline pIJ702 & $\mathrm{Ts}^{\mathrm{r}} \mathrm{Mel}^{+}$ & Katz et al. (1983) \\
\hline pIJ903 & $T s^{r} A p^{r}$ & Lydiate et al. (1985) \\
\hline
\end{tabular}

thermoviolaceus CUB74 was grown at $50^{\circ} \mathrm{C}$ in half-strength nutrient broth or on half-strength nutrient agar; $S$. lividans TK24 was grown on R2YE (solid) or YEME (liquid) media with and without sucrose (Hopwood et al., 1985). These media were supplemented with $1 \%$ (w/v) potato starch in order to visualize any amylase activity on plates, and thiostrepton $\left(50 \mu \mathrm{g} \mathrm{ml}^{-1}\right)$ was added when required.

Isolation of total DNA and plasmids. Total DNA was prepared by a slightly modified method of that described by Chater et al. (1982). Mycelia, harvested from an overnight liquid culture of CUB74, were resuspended in $20 \mathrm{ml}$ Birnboim buffer $(25 \mathrm{mM}-\mathrm{Tris} / \mathrm{HCl}, \mathrm{pH} 7.5$, $10 \mathrm{mM}-\mathrm{Na}_{2}$ EDTA, $0.9 \%$, w/v, glucose, $2 \mathrm{mg}$ lysozyme $\mathrm{ml}^{-1}$ ). After adding SDS to a final concentration of $1 \%(\mathrm{w} / \mathrm{v}), 4 \mathrm{ml}$ pronase solution ( $10 \mathrm{mg} \mathrm{ml}^{-1}$; pre-self-digested at $37^{\circ} \mathrm{C}$ for $2 \mathrm{~h}$ ) was mixed with the preparation. This was then mixed with $4 \mathrm{ml}$ TE buffer $(10 \mathrm{mM}$ Tris/ $\mathrm{HCl}, \mathrm{pH} 7.5,1 \mathrm{mM}$-EDTA) plus RNAase $\left(20 \mu \mathrm{g} \mathrm{ml}^{-1}\right)$ and incubated at $37^{\circ} \mathrm{C}$ for $1 \mathrm{~h}$. Then $5 \mathrm{ml}$ of the same buffer was added and incubation was continued for a further $2 \mathrm{~h}$ at the same temperature. Finally, $1 \mathrm{ml} 5 \mathrm{M}-\mathrm{NaCl}$ was added, $20 \mathrm{ml}$ of ethanol was layered on and the DNA was spooled with a flame-blunted Pasteur pipette. The DNA was resuspended in $18 \mathrm{ml}$ TE buffer and purified on a caesium chloride/ethidium bromide gradient if necessary.

Plasmid isolation on a large scale was done by the method of Bibb et al. (1977). Small-scale preparation of plasmid DNA was performed as described by Birnboim \& Doly (1979).

Cloning and expression of the amylase gene in E. coli. All restriction endonuclease digestions and ligations were performed as described by Maniatis et al. (1982). Agarose gels $(1 \%, \mathrm{w} / \mathrm{v})$ were used to separate the DNA bands.

Chromosomal DNA of $S$. thermoviolaceus CUB74 was digested to completion with BamHI and ligated to pUC8 that had been cut with the same restriction enzyme. The genomic library was then used to transform competent E. coli JM107. All ampicillin-resistant (Ap ${ }^{r}$ colonies obtained were replicated on to starch plates using sterile velvet pads.

Restriction endonuclease mapping and subcloning. The following restriction endonucleases were used: EcoRI, HindIII, BamHI, PstI, $B g / \mathrm{II}, X h o \mathrm{I}, S p h \mathrm{I}, \mathrm{KpnI}, S m a \mathrm{I}, S a l \mathrm{GI}, B c / \mathrm{I}$ and $S a c \mathrm{I}$. $\lambda$ DNA digested with HindIII was used as a size marker. The map of the insert is shown in Fig. 1. In order to locate the amylase gene (amy) on the insert, pQR300 (pUC8 plus insert) was double digested to completion with $B a m H I / B g / I I$, extracted with phenol/chloroform and then religated. For the same purpose, the $1.7 \mathrm{~kb} \mathrm{BamHI}-S p h \mathrm{I}$ fragment was extracted from an agarose gel (Girvitz et al., 1980) and cloned into pUC18 that had been cut with the same restriction enzymes. In addition, and in order to determine whether the amylase gene is expressed from the lac $Z$ promoter on pUC8 or from its own promoter, cloning of the whole insert in the opposite orientation to the lac $Z$ promoter was performed by digesting pQR300 with BamHI and religating it. The orientation of the insert was determined by isolating and mapping plasmids from both amylase-negative and amylase-positive colonies. For the same purpose, the whole insert was subcloned in the BgIII site of pQR 1 , which lacks the lac $Z$ promoter.

For the cloning and expression in $S$. lividans, the amylase gene carried by the $5.7 \mathrm{~kb} \mathrm{BamHI}$ fragment was cloned into the shuttle vector $\mathrm{pQR} 1$ that had been cut with BglII. Recombinant plasmids (pQR308 and pQR309) were isolated from E. coli and used to transform $S$. lividans. The high-copy-number streptomycete vector $\mathrm{pIJ} 702$ was also used for subcloning. The plasmid was cut with $B g I I I$ and $S p h I$ and ligated to the $1.7 \mathrm{~kb}$ Bam HI-SphI DNA fragment carrying the amylase gene. The recombinant plasmid construct obtained was called pQR311. The low-copy-number plasmid pIJ903 was also used for cloning in both $E$. coli and $S$. lividans. A $1.7 \mathrm{~kb}$ BamHI-HindIII DNA fragment from pQR307, generated by partial HindIII digestion and complete BamHI digestion, was inserted between the BamHI and HindIII sites of pIJ903. The resulting plasmid was called pQR319.

Preparation of $S$. lividans protoplasts and their transformation were performed as described by Hopwood et al. (1985).

Preparation of enzyme, protein determination and SDS-PAGE. Total extracellular enzymes (concentrated 100-fold) were prepared from $E$. coli and Streptomyces cultures by precipitating with ammonium sulphate $(90 \%$ saturation). The precipitate was resuspended in $20 \mathrm{~mm}-$ Tris $/ \mathrm{HCl}$, pH 7.5, $5 \mathrm{mM} \mathrm{CaCl}_{2}$, dialysed twice (1 $\mathrm{h}$ each) against the same buffer at room temperature and once overnight against the same buffer containing $50 \%(\mathrm{v} / \mathrm{v})$ glycerol at $4{ }^{\circ} \mathrm{C}$, and finally stored at $-20{ }^{\circ} \mathrm{C}$.

The Bio-Rad Protein Assay was used to determine the protein concentration as described by the supplier. Approximately $80-100 \mu \mathrm{g}$ of protein was subjected to $10 \%$ SDS-PAGE (Fig. 2) for molecular mass determination (Laemmli, 1970). The proteins were denatured by mixing with $50 \mu \mathrm{l}$ loading buffer $(5 \%, \mathrm{v} / \mathrm{v}$, mercaptoethanol, $3.4 \%$, w/v, SDS, $15 \%, v / v$, glycerol, $0.01 \%, w / v$, bromophenol blue, $47 \mathrm{~mm}-$ Tris/ $\mathrm{HCl}, \mathrm{pH} 6.8$ ) and boiling at $100{ }^{\circ} \mathrm{C}$ for $3 \mathrm{~min}$, and were run in duplicate. They were renatured by washing half the gel twice with $2.5 \%$ $(\mathrm{w} / \mathrm{v})$ Triton $\mathrm{X}-100,1 \mathrm{~h}$ each, and then rinsing it in $20 \mathrm{mM}-\mathrm{Tris} / \mathrm{HCl}$, pH $7 \cdot 5,5 \mathrm{~mm}-\mathrm{CaCl}_{2}$ for $25 \mathrm{~min}$ at room temperature. The position of the enzyme activity was located by sandwiching the reactivated gel against a $1 \%(\mathrm{w} / \mathrm{v})$ agarose gel made in the $\mathrm{Tris} / \mathrm{HCl}$ buffer and containing $0.5 \%$ potato starch. The sandwich was incubated overnight at $37^{\circ} \mathrm{C}$ between two glass plates and under a weight. Starch hydrolysis zones were detected by soaking the agarose gel in $0.05 \%(\mathrm{w} / \mathrm{v}) \mathrm{I}_{2}, 2.65 \%$ $(w / v)$ KI (Siggens, 1987). The other half of the protein gel also contained molecular mass markers (from Sigma) and was stained with Coomassie Brilliant Blue R. 
Amylase assay and paper chromatography. Enzyme units were calculated by carrying out a modified Somogyi assay (Nelson, 1944) in which $500 \mu \mathrm{l}$ of an enzyme preparation was mixed with $500 \mu \mathrm{l}$ of $1 \%$ $(\mathrm{w} / \mathrm{v})$ soluble starch (in the same Tris/ $\mathrm{HCl}$ buffer plus $5 \mathrm{~mm}-\mathrm{CaCl}_{2}$ ). After $1 \mathrm{~h}$ incubation at $50^{\circ} \mathrm{C}, 100 \mu \mathrm{l}$ was removed from the mixture and added to $900 \mu \mathrm{l}$ of distilled water. Then $1 \mathrm{ml}$ of a mixture of reagent $A$ and reagent $B$ as specified by Nelson (1944) was added and mixed. The mixture was heated at $100{ }^{\circ} \mathrm{C}$ for $20 \mathrm{~min}$, cooled and $1 \mathrm{ml}$ of the arsenomolybdate reagent was added. After complete evolution of $\mathrm{CO}_{2}$, the mixture was added to $10 \mathrm{ml}$ distilled water and the absorbance read at $600 \mathrm{~nm}$. One unit of amylase was defined as the amount of enzyme which releases $1 \mathrm{mg}$ reducing sugar from soluble starch in $1 \mathrm{~h}$ at $50^{\circ} \mathrm{C}$ and $\mathrm{pH} 7 \cdot 5$. A standard curve was made using maltose.

The product of starch hydrolysis by amylase was analysed by paper chromatography using 2-propanol/water $(7: 3, v / v)$ as solvent and silver nitrate as a stain (Robyt \& French, 1963).

\section{Results}

Cloning and expression of the amylase gene in E. coli

Transformation of E. coli JM107 by the Bam HI library of $S$. thermoriolaceus CUB74 DNA in pUC8 resulted in more than $10000 \mathrm{Ap}^{\mathrm{r}}$ colonies, $64 \%$ of which were colourless on X-gal plates and presumed to be recombinants. After replicating on starch plates, one colony showed extensive amylase activity and a zone of starch hydrolysis was observed with or without iodine staining. This amylase-positive colony was found to have a recombinant plasmid, pQR300, containing an insert of $5.7 \mathrm{~kb}$ (Fig. 1). pQR300 was used to transform E. coli and $100 \%$ of the colonies obtained were amylase positive. On starch plates, pUC8-containing E. coli colonies (control) produced no hydrolysis zones. Approximately $40 \%$ of the amylase actıvity expressed by $E$. coli J M107(pQR300) was present in the culture supernatant (extracellular fraction); the remainder $(60 \%)$ was located in the periplasm/cytoplasmic fraction (Table 2). Alkaline phosphatase was used as a periplasmic marker.

Surprisingly, IPTG, added to liquid modium, induced the amylase production by $E$. coli JM107(pQR300) but not substantially (by $16 \%$ only); on plates, larger hydrolysis zones were obtained in the presence of IPTG. Transformation of E. coli JM107 with pQR303 (Fig. 1), where the $5.7 \mathrm{~kb}$ BamHI fragment was cloned in the opposite orientation to the lac $Z$ promoter, yielded amylase-negative colonies only. Furthermore, cloning of the $5.7 \mathrm{~kb} B a m \mathrm{HI}$ fragment into the $B g / \mathrm{II}$ site of $\mathrm{pQR} 1$ to give the plasmids pQR308 and pQR309 resulted in amylase-negative $E$. coli colonies. The Bg/II site is in the $m e l$ operon, which is not expressed in E. coli. It was therefore concluded that the expression of the amylase gene was from the lac $Z$ promoter in the pUC8 derivatives and not from its own promoter. The low level of induction by IPTG may be explained by the high copy
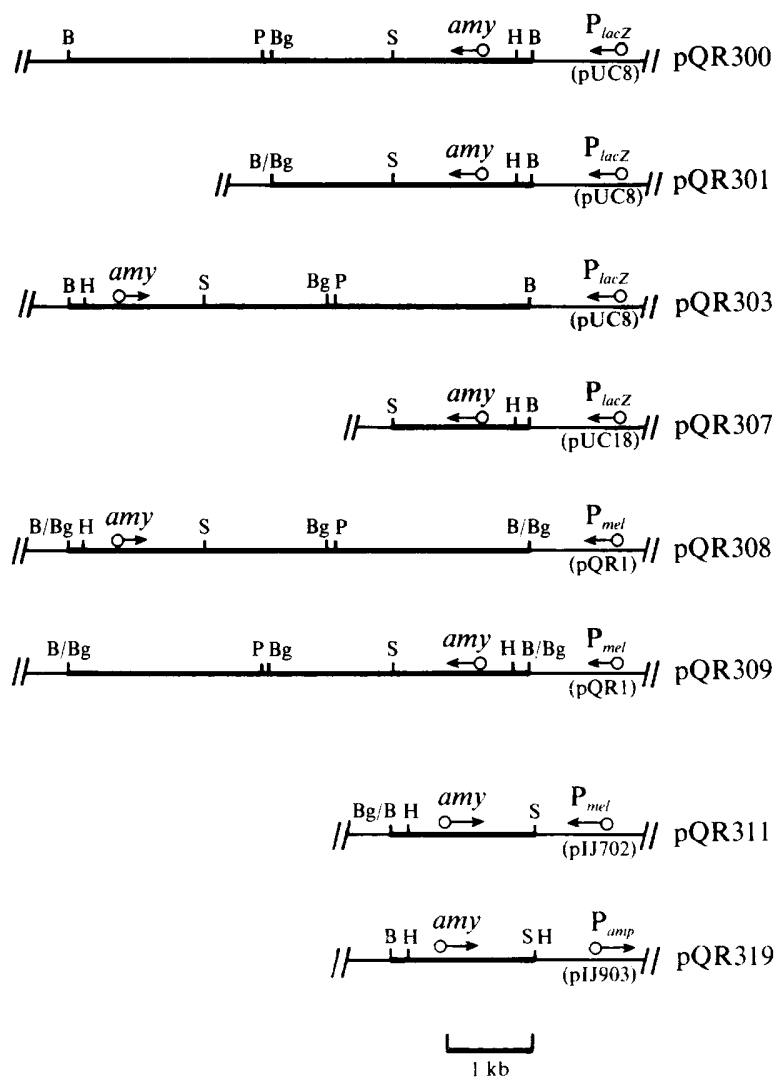

Fig. 1. Restriction enzyme map of $\mathrm{pQR} 300$ and plasmids obtained from subcloning experiments. The construction of these plasmids is described in Methods. The arrows represent the orientation of the amylase gene (amy) in relation to the lac $Z$ promoter $\mathrm{P}_{\text {lac }}$ on $\mathrm{pUC} 8$ and pUC18, the mel promoter $\left(\mathrm{P}_{m e l}\right)$ on pQR1 and pIJ702 (in the case of pQR308, pQR309 and pQR311), and the ampicillin promoter $\left(\mathbf{P}_{\text {amp }}\right)$ on pIJ903 (in the case of pQR 319). B, BamHI; P, PstI ; Bg, Bg/II; S, Sphl : $\mathrm{H}$, HindIII.

number of the plasmid, which titrates out a proportion of the lacl repressor even in strains containing the $l a c I^{9}$ allele (Stewart et al., 1986).

The Streptomyces origin of the amylase gene was confirmed by probing a BamHI bulk digestion of $S$. thermoviolaceus CUB74 total DNA (Southern, 1975) with radioactively labelled pQR300 (data not shown). A single $5.7 \mathrm{~kb}$ BamHI fragment of CUB74 showed homology with the probe.

\section{Mapping and subcloning}

The map of the insert and the plasmids resulting from subcloning are shown in Fig. 1. It was found that the amylase gene is carried by a $1.7 \mathrm{~kb} B a m \mathrm{HI}-S p h \mathrm{I}$ fragment (pQR307) and starts from the side of the BamHI site as deduced from the lack of $\alpha$-amylase expression from E. coli harbouring pQR303. Plasmids 
A

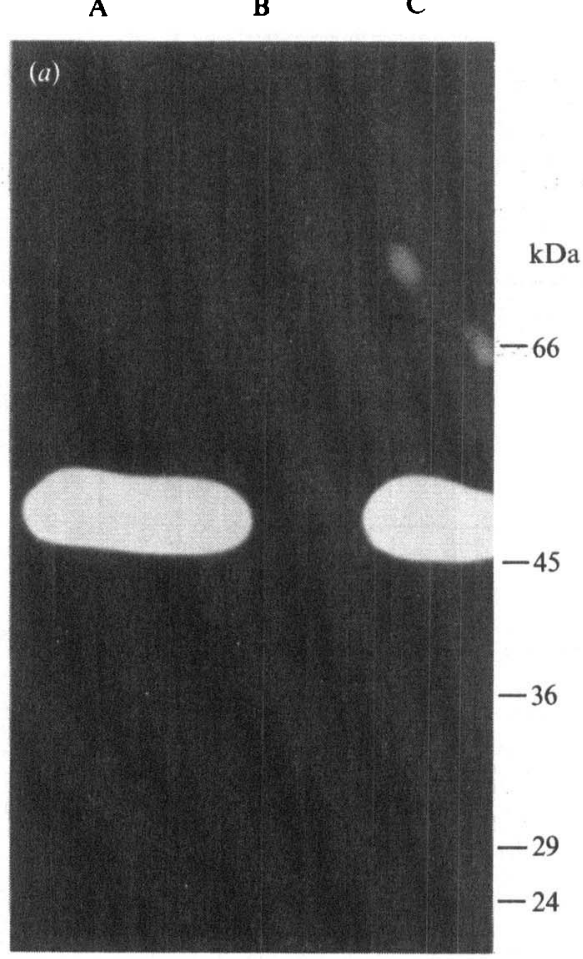

A

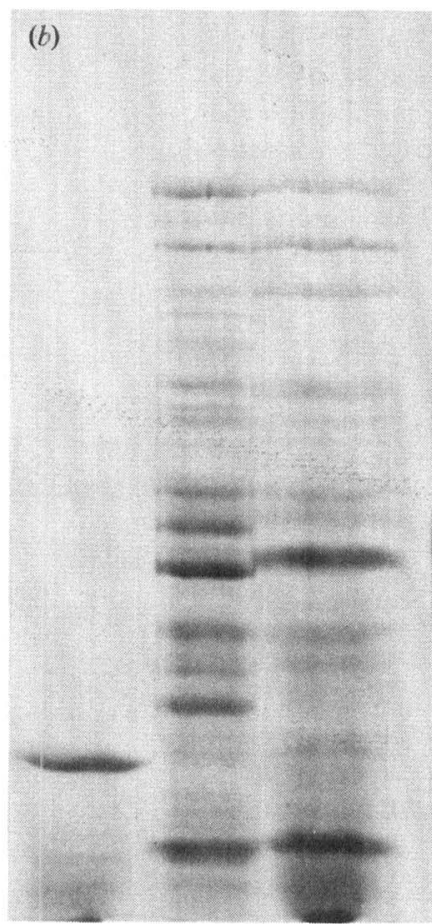

A

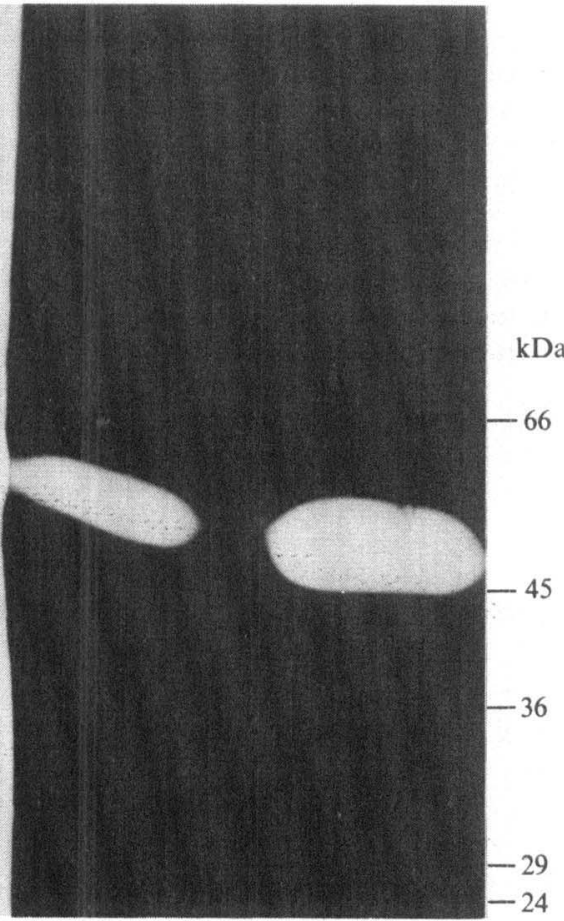

Fig. 2. SDS-PAGE. Approximately $80 \mu \mathrm{g}$ of $E$. coli and $S$. thermoviolaceus CUB 74 crude supernatants (concentrated 100-fold) and $100 \mu \mathrm{g}$ of $S$. lividans supernatants were loaded on the gel. Protein samples were run in duplicate on the same gel. An agarose gel containing potato starch was overlaid on the reactivated half of the protein gel and stained with iodine as described in Methods. The other half of the gel, which also contained molecular mass markers, was stained with Coomassie Brilliant Blue R. (a) (Activity stain only): A, E. coli JM107(pQR300); B, E. coli JM107(pUC8) (control); C, S. thermoviolaceus CUB74. (b) A, S. thermoviolaceus CUB74, B, S. lividans TK24(pIJ702) (control); C, S. lividans TK24(pQR311). The molecular mass markers were bovine serum albumin (66 kDa), egg albumin ( $45 \mathrm{kDa})$ glyceraldehyde-3-phosphate dehydrogenase $(36 \mathrm{kDa})$, carbonic anhydrase $(29 \mathrm{kDa})$ and trypsinogen, PMSF treated $(24 \mathrm{kDa})$.

Table 2. Localization of amylase expressed by E. coli $J M 107(p Q R 300)$

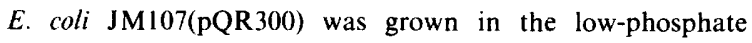
medium of $\mathrm{Neu} \&$ Heppel (1964) to an $\mathrm{OD}_{450}$ of 1.0 and fractionated by the method of Minton et al. (1983). Alkaline phosphatase was assayed by the method of Torriani (1966); amylase was assayed as described in Methods. This experiment was repeated three times and the results obtained were consistent, varying by only $3-5 \%$.

\begin{tabular}{lcc}
\hline & \multicolumn{2}{c}{$\begin{array}{c}\text { Percentage of } \\
\text { enzyme activity }\end{array}$} \\
\cline { 2 - 3 } Fraction & $\begin{array}{c}\text { Alkaline } \\
\text { phosphatase }\end{array}$ & Amylase \\
\hline Supernatant & 9 & $43 \cdot 2$ \\
Periplasm/cytoplasm & 91 & $56 \cdot 8$ \\
Membrane bound & 0 & 0 \\
\hline \hline
\end{tabular}

pQR308 and pQR309 isolated from E. coli were used to transform $S$. litidans TK24 and thiostrepton-resistant $\left(\mathrm{Ts}^{r}\right)$ colonies were selected. These plasmid constructs
(pQR308 and 309) were extremely unstable in S. lividans. They rearranged and lost the amylase gene.

Cloning in S. lividans was successful when the BamHI$S p h I$ fragment carrying the amylase gene, was inserted into the high-copy-number plasmid pIJ702 which had been cut with $B g / \mathrm{II} / S p h \mathrm{I}$ and $\mathrm{Mel}^{-} \mathrm{Ts}^{\mathrm{r}}$ colonies were selected for. The recombinant plasmid was designated pQR311. Large amylase zones were produced by $S$. lividans TK24(pQR311) colonies whereas the control, TK24(pIJ702), produced small zones. The $1.7 \mathrm{~kb}$ BamHI-SphI fragment was also subcloned into the lowcopy-number plasmid pIJ903 and the recombinant plasmid (pQR319) was introduced to $E$. coli and $S$. lividans. E. coli colonies containing this construct were amylase negative whereas $S$. lividans containing the construct produced large amylase zones on starch plates.

\section{SDS-PAGE and characterization of amylase}

Concentrated crude culture supernatants of E. coli and S. thermoviolaceus CUB74 were analysed on the same 
gel (Fig. 2a). E. coli JM107(pQR300) (lane A) and $S$. thermotiolaceus CUB74 (lane C) showed a starchdegrading activity corresponding to a protein of the same size $(50 \mathrm{kDa})$ after renaturation of the proteins in the SDS polyacrylamide gel. This similarity in molecular mass suggests that $E$. coli can correctly process the amylase protein to the form found in the parent Streptomyces strain. Coomassie staining of protein bands in the gel (results not shown) revealed comigration of the amylases from E. coli JM107(pQR300) and S. thermoviolaceus CUB74, showing that the processing of the signal peptide by $E$. coli could differ by no more than a few amino acids. This preliminary result is currently being resolved by sequencing the $\mathrm{N}$-terminus of both proteins. There was no detectable amylase activity from the pUC8-containing E. coli control (Fig. $2 a$, lane B).

The amylase produced by pQR311-containing $S$. lividans also had the same size as that of CUB74, and no amylase activity was detectable in the reactivated gel system from pIJ702-containing $S$. lividans (Fig. $2 b$ ).

\section{Paper chromatography analysis}

Paper chromatography of starch digestion products showed that maltose was the major end-product and started to appear as a distinct spot at $1.5 \mathrm{~h}$. Glucose, however, appeared in small amounts at $8 \mathrm{~h}$. From this result, it was concluded that the enzyme is an $\alpha$-amylase as the major products are maltotetraose, maltotriose and maltose, with maltose accumulating over extended periods while maltotetraose disappears.

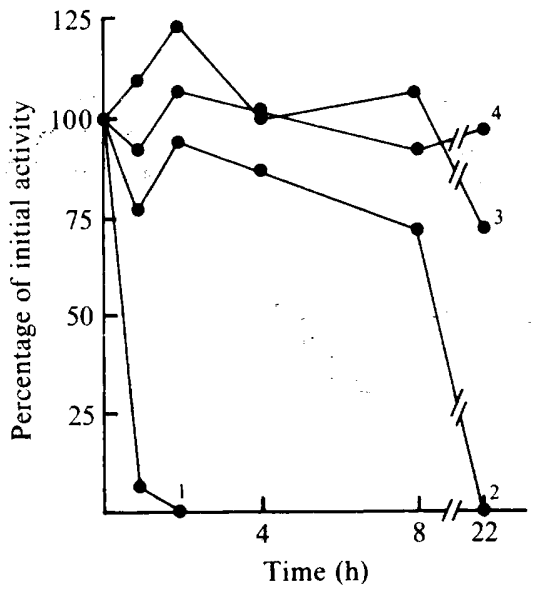

Fig. 3. Effect of $\mathrm{Ca}^{2+}$ on heat stability of the enzyme. Cultures $(5 \mathrm{ml})$ of E. coli JM107(pQR300) were grown overnight at $37^{\circ} \mathrm{C}$ in nutrient broth with and without $5 \mathrm{~mm}-\mathrm{CaCl}_{2}$. Samples $(500 \mu \mathrm{l})$ of their supernatants were preincubated at 50 or $60{ }^{\circ} \mathrm{C}$ for the time indicated and then assayed at $50^{\circ} \mathrm{C}$. The $1 \%$ soluble starch solution used in this assay was made up in $20 \mathrm{~mm}$-Tris/ $\mathrm{HCl} \mathrm{pH} 7.5$ buffer plus $5 \mathrm{~mm}-\mathrm{CaCl}_{2}$. 1, In the absence of $\mathrm{CaCl}_{2}$ and at $60^{\circ} \mathrm{C} ; 2$, in the absence of $\mathrm{CaCl}_{2}$ and at $50{ }^{\circ} \mathrm{C} ; 3$, in the presence of $\mathrm{CaCl}_{2}$ and at $60{ }^{\circ} \mathrm{C} ; 4$, in the presence of $\mathrm{CaCl}_{2}$ and at $50^{\circ} \mathrm{C}$. These experiments have been repeated and the results are reproducible.

\section{Temperature stability}

The temperature stability of the enzyme was examined in the presence and absence of $\mathrm{CaCl}_{2}$ by preincubating in the absence of substrate. In the presence of $5 \mathrm{~mm}-\mathrm{CaCl}_{2}$, the amylase secreted by E. coli JM107(pQR300) retained

Table 3. Effect of temperature on enzyme activity

E. coli JM107(pQR300) was grown with and without $5 \mathrm{mM}-\mathrm{CaCl}_{2}$ overnight at $37^{\circ} \mathrm{C}$. Samples $(500 \mu \mathrm{l})$ of each culture supernatant were preincubated at the temperature indicated for $1 \mathrm{~h}$ and then assayed at $50^{\circ} \mathrm{C}$ as described in Methods. The $1 \%$ soluble starch used in the enzyme assay was made up in $20 \mathrm{~mm}$-Tris/ $\mathrm{HCl}$ buffer $\mathrm{pH} 7.5$ plus $5 \mathrm{~mm}-\mathrm{CaCl}_{2}$. This experiment has been repeated three times and the results were within $4 \%$ of those shown below.

\begin{tabular}{|c|c|c|c|c|}
\hline \multirow[b]{2}{*}{ Temp. $\left({ }^{\circ} \mathrm{C}\right)$} & \multicolumn{2}{|c|}{ Minus $\mathrm{CaCl}_{2}$} & \multicolumn{2}{|c|}{ Plus $\mathrm{CaCl}_{2}$} \\
\hline & $\begin{array}{l}\text { Activity } \\
\left(\mathrm{U} \mathrm{ml}^{-1}\right)\end{array}$ & $\begin{array}{l}\text { Percentage of } \\
\text { max. activity }\end{array}$ & $\begin{array}{l}\text { Activity } \\
\left(\mathrm{U} \mathrm{ml}^{-1}\right)\end{array}$ & $\begin{array}{l}\text { Percentage of } \\
\text { max. activity }\end{array}$ \\
\hline 4 & 3.62 & 88 & $2 \cdot 5$ & 88 \\
\hline 37 & $4 \cdot 1$ & 100 & 2.84 & 100 \\
\hline 50 & $3 \cdot 64$ & 89 & $2 \cdot 58$ & 90 \\
\hline 60 & 0.62 & 15 & $2 \cdot 52$ & 89 \\
\hline 70 & 0.52 & 13 & 2 & 70 \\
\hline 80 & 0.1 & 2 & $0 \cdot 3$ & 11 \\
\hline
\end{tabular}


$90 \%$ of its activity at $60{ }^{\circ} \mathrm{C}$ and $70 \%$ of its activity at $70{ }^{\circ} \mathrm{C}$ after preincubation for $1 \mathrm{~h}$ at these temperatures (Table 3). Most of this activity was abolished above $80^{\circ} \mathrm{C}$. In the absence of $\mathrm{CaCl}_{2}$, the amylase activity rapidly fell at temperatures above $50{ }^{\circ} \mathrm{C}$. Fig. 3 shows that in the absence of $\mathrm{CaCl}_{2}$, the enzyme lost $30 \%$ of its activity after $8 \mathrm{~h}$ incubation at $50^{\circ} \mathrm{C}$ and it was totally inactive after $22 \mathrm{~h}$ at $50^{\circ} \mathrm{C}$ and $2 \mathrm{~h}$ at $60^{\circ} \mathrm{C}$. It also shows that in presence of $\mathrm{CaCl}_{2}$, the enzyme was $100 \%$ stable after $22 \mathrm{~h}$ incubation at $50{ }^{\circ} \mathrm{C}$ and $8 \mathrm{~h}$ at $60^{\circ} \mathrm{C}$.

\section{Discussion}

The $\alpha$-amylase gene of $S$. thermoviolaceus CUB74 has been cloned and expressed in $E$. coli and more than $40 \%$ of its product was secreted into the medium. It is the exception rather than the rule for enzymes which are extracellular in their original Gram-positive host to be exported into the culture medium when cloned in E. coli. In most cases, Gram-positive extracellular enzymes are periplasmic when expressed in E. coli (Pugsley, 1988). It is not clear at this stage whether any other protein(s) beside the $\alpha$-amylase are required for the extracellular location in E. coli. The smallest insert still expressing amylase is $1.7 \mathrm{~kb}$. DNA sequencing of this and further subcloning will reveal whether all the information for secretion beyond the periplasmic space is located in the coding sequence of the amy gene.

The expression of amy in E. coli was not observed when the insert was subcloned either in the opposite orientation to the lac $Z$ promoter or in a vector that lacks this promoter (pQR1). This barrier to expression of Streptomyces genes in $E$. coli has been previously observed (Horinouchi et al., 1980; Bibb \& Cohen, 1982; Rodgers et al., 1982). On the other hand, while the expression of amylase seemed to be possibly from the lac $Z$ promoter, its production was not substantially induced by IPTG. This, in theory, might be a result of the high-copy-number of the plasmid, which may titrate out the lacI repressor. Hoshiko et al. (1987) reported the induction, in $E$. coli, of $S$. hygroscopicus $\alpha$-amylase. They found that the enzyme, whose gene had been cloned in pUC12, was induced approximately sevenfold in the presence of IPTG.

The molecular mass of the secreted $\alpha$-amylase of CUB 74 determined by SDS-PAGE was $50 \mathrm{kDa}$, which, within the errors of the method, is the same as that of the enzyme secreted by $E$. coli and $S$. lividans. This similarity may result from the ability of $E$. coli to process the signal peptide correctly as in the original Streptomyces host. This result can only be proven by sequencing the $\mathrm{N}$ terminus of the secreted enzyme from both strains. It is not a general case that $E$. coli will process the signal peptide in exactly the same manner as a Gram-positive organism: e.g. the endo- $\beta$ - $N$-acetylglucosidase $\mathrm{H}$ in its natural host, $S$. plicatus, is smaller than when it is expressed by $E$. coli (Robbins et al., 1981); it was therefore suggested that a secondary cleavage, which occurs in Gram-positive secreted proteins, does not occur when the protein is synthesized and secreted into the periplasmic space by E. coli (Robbins et al., 1984). In our experiments, the $S$. thermoviolaceus amylase was secreted into the culture medium of $E$. coli cells containing $\mathrm{pQR} 300$ under conditions where alkaline phosphatase, a periplasmic enzyme, was still retained up to $91 \%$ in the periplasm/cytoplasmic fraction (Table 2). This implies a specific release of the amylase into the medium rather than a non-specific release of periplasmic proteins as has been seen when there is overproduction of periplasmic proteins (Suominen et al., 1987).

In order to study the expression of amylase in $S$. lividans, low (plJ903) (Lydiate et al., 1985) and high ( $\mathrm{pQR} 1$ ) copy-number shuttle vectors were used. When the $B g / \mathrm{II}$ site of $\mathrm{pQR} 1$ was used for cloning, the resulting plasmid constructs (pQR308 and 309) were stable in $E$. coli. However, they were very unstable in S. lividans and underwent large deletions which removed the cloned DNA and a part of the vector. Similar problems were also encountered when the $5.7 \mathrm{~kb}$ BamHI fragment was inserted in the $B g / I I$ site of pIJ702. This could be due to the presence of unstable sequences carried by the insert. This was avoided by cloning a smaller DNA fragment, a $1.7 \mathrm{~kb} \mathrm{BamHI-SphI}$ fragment, in pIJ702. The recombinant plasmid construct $\mathrm{pQR} 311$ was stable and expression of the amylase gene was obtained. Our results strongly suggest that the amylase gene is transcribed in the direction of BamHI to SphI in the $1.7 \mathrm{~kb}$ fragment inserted into pIJ702. This would place the amylase gene in the opposite orientation with respect to the mel promoter of pIJ702 in pQR311. It is not known yet whether the $1.7 \mathrm{~kb}$ fragment contains the promoter of the amylase gene or whether expression in $S$. lividans is caused by readthrough from promoters within the vector.

The activity expressed by the cloned $\alpha$-amylase gene in $E$. coli has a surprisingly extended stability in the presence of $\mathrm{Ca}^{2+}$. At $50{ }^{\circ} \mathrm{C}, 100 \%$ of the starting activity remained after $22 \mathrm{~h}$ (Fig. 3). At $60^{\circ} \mathrm{C}$, this had only dropped to $75 \%$ after $22 \mathrm{~h}$. From the data shown in Table $3,70 \%$ of the starting activity remained after $1 \mathrm{~h}$ at $70{ }^{\circ} \mathrm{C}$ in the presence of $\mathrm{Ca}^{2+}$. The presence of $\mathrm{Ca}^{2+}$ therefore substantially increases the stability to thermal denaturation. The effect of $\mathrm{Ca}^{2+}$ on the thermal stability of several extracellular proteins is well known: for example many extracellular enzymes from Bacillus species are stabilized by binding $\mathrm{Ca}^{2+}$ (Normen, 1979). 
The stability of the $\alpha$-amylase in the presence of substrate has not been extensively tested but preliminary results (data not shown) suggest an even greater stability in the presence of starch and $\mathrm{Ca}^{2+}$ than for $\mathrm{Ca}^{2+}$ alone. This enzyme may be a candidate for constructing promoter-probe vectors or for protein fusion studies since it is easily assayed and its expression leads to the appearance of zones around colonies on starch plates even before staining with iodine. It is expressed in E. coli and secreted in high amounts into the culture medium. This makes its isolation easy since it avoids problems associated with cell breakage. Furthermore, the enzyme assay can be carried out at a high temperature, $60-70^{\circ} \mathrm{C}$, which eliminates background caused by any amylase activity of a mesophilic host, e.g. S. lividans.

This work was supported by a grant from the Hariri Foundation to S.M.B. and by a grant from the SERC Biotechnology Directorate to J. M. W. We thank R. Barallon for supplying pQR1. Thiostrepton was a generous gift of S. J. Lucania. The Squibb Institute for Medical Research, New Jersey.

\section{References}

BibB, M. J. \& CohEn, S. N. (1982). Gene expression in Streptomyces: construction and application of promoter-probe plasmid vectors in Streptomyces lividans. Molecular and General Genetics 187, 265-277.

BibB, M. J., Freeman, R. F. \& Hopwood, D. A. (1977). Physical and genetical characterization of a second sex factor, SCP2, for Streptomyces coelicolor A3(2). Molecular and General Genetics 154, $155-166$

BibB, M. J., Chater, K. F. \& Hopwood, D. A. (1983). Developments in Streptomyces cloning. In Experimental Manipulation of Gene Expression. pp. 54-80. Edited by M. Inouye. London: Academic Press.

Birnboim, H. C. \& Doly, J. (1979). A rapid alkaline extraction procedure for screening recombinant plasmid DNA. Nucleic Acids Research 7, 1513-1523.

Chater, K. F., Hopwood, D. A., Kieser, T. \& Thompson, C. J. (1982). Gene cloning in Streptomyces. Current Topics in Microbiology and Immunology 97, 69-95.

GiL, J. A., Kieser, H. M. \& Hopwood, D. A. (1985). Cloning of a chloramphenicol acetyltransferase gene of Streptomyces acrimycini and its expression in Streptomyces and Escherichia coli. Gene 38, 1-8.

Girvitz, S. C. BACChetti, S., Rainbow, J. A. \& Graham, L. F. (1980). $A$ rapid and efficient procedure for the purification of DNA from agarose gels. Analytical Biochemistry 106, 492.

Hercomb, J., Thierbach, G., Baumberg, S. \& Parish, J. H. (1987). Cloning, characterization and expression in Escherichia coli of a leucine biosynthetic gene from Streptomyces rochei. Journal of General Microbiology 133, 317-322.

HopwoOd. D. A., KeISER, T., Wright, M. H. \& BibB, M. J. (1983). Plasmids, recombination and chromosome mapping in Streptomyces lividans 66. Journal of General Microbiology 129, 2257-2269.

Hopwood, D. A., BibB, M. J., Chater, K. F., Kieser, T., Bruton, C. J., Kieser, H. M., Lydiate, D. J., Smith, C. P., WARD, J. M. \& SCHREMPF. H. (editors) (1985). Genetic Manipulation of Streptomyces: A Laburatory Manual. Norwich: The John Innes Foundation.

Horinouchi, S., UOzumi, T. \& BePPU, T. (1980). Cloning of Streptomyces DNA into Escherichia coli; absence of heterospecific gene expression of Streptomyces genes in Escherichia coli. Agricultural and Biological Chemistry 44, 367-371.
Hoshiko, S., Makabe, O., Nojiri, C., Katsumata, K., Satoh, E. \& NAGAOKA, K. (1987). Molecular cloning and characterization of the Streptomyces hygroscopicus $\alpha$-amylase gene. Journal of Bacteriology 169, 1029-1036.

Katz, F., Thompson, C. J. \& Hopwood, D. A. (1983). Cloning and expression of the tyrosinase gene from Streptomyces antibioticus in Streptomyces lividans. Journal of General Microbiology 129, 27032714.

LAEMmLI, U. K. (1970). Cleavage of structural proteins during the assembly of the head of bacteriophage T4. Nature, London 227, 680 685 .

Ljungdahl, L. G. (1979). Physiology of thermophilic bacteria. Advances in Microbial Physiology 19, 149-243.

Long, C. M., Virolle, M.-J., Chang, S. \& BibB, M. J. (1987). $\alpha$ Amylase gene of Streptomyces limosus: nucleotide sequence, expression motifs and amino acid sequence homology to mammalian and invertebrate $\alpha$-amylase. Journal of Bacteriology 169, 5745-5754.

Lydiate, D. J., Malpartida, F. \& Hopwood, D. A. (1985). The Streptomyces plasmid SCP2*: its functional analysis and development into useful cloning vectors. Gene 35, 223-235.

Maniatis, T., Fritsch, E. F. \& SambroOK, J. (editors) (1982). Molecular Cloning : A Laboratory Manual. Cold Spring Harbor, NY: Cold Spring Harbor Laboratory.

MCKillop, C., Elvin, P. \& Kenten, J. (1986). Cloning and expression of an extracellular $\alpha$-amylase gene from Streptomyces hygroscopicus in Streptomyces lividans 66. FEMS Microbiology Letters 36, 3-7.

MEADE, H. (1985). Cloning of arg $G$ from Streptomyces: loss of gene in $\mathrm{Arg}^{-}$mutants of Streptomyces cattleya. Biotechnology 3, 917-918.

Minton, N. P., AtKinson, T. \& SHER wood, R. F. (1983). Molecular cloning of the Pseudomonas carboxypeptidase $\mathrm{G}_{2}$ gene and its expression in Escherichia coli and Pseudomonas putida. Journal of Bacteriology 156, 1222-1227.

NeLSON, N. (1944). A photometric adaptation of the Somogyi method for the determination of glucose. Journal of Biological Chemistry 153, 375-380.

Neu, H. C. \& Heppel, L. A. (1964). The release of enzymes from Escherichia coli by osmotic shock and during the formation of spheroplasts. Journal of Biological Chemistry 240, 3685-3692.

NORMEN, B. E. (1979). The application of polysaccharide degrading enzymes in the starch industry. In Microbial Polysaccharides and Polysaccharases, pp. 338-376. Edited by R. C. W. Berkeley, G. W. Gooday \& D. C. Ellwood. London: Academic Press.

PugsLeY, A. P. (1988). Getting out of Escherichia coli: protein secretion across the Gram-negative outer membrane. In Protein Transfer and Organelle Biogenesis, pp. 607-652. Edited by R. C. Das \& P. W. Robbins. London: Academic Press.

Robbins, P. W., Wirth, D. F. \& Hering, C. (1981). Expression of the Streptomyces enzyme endoglycosidase $\mathrm{H}$ in Escherichia coli. Journal of Biological Chemistry 256, 10640-10644.

Robbins, P. W., Trimble, R., Wirth, D. F., Hering, C., Maley, F., Maley, G., Das, R., Gilson, B. W., Royal, N. \& Bieman, K. (1984). Primary structure of Streptomyces enzyme endo- $\beta$ - $N$-acetylglucosamidase H. Journal of Biological Chemistry 259, 7577-7583.

ROBYT, J. \& FRENCH, D. (1963). Action pattern and specificity of an amylase from Bacillus subtilis. Archives of Biochemistry and Biophysics $100,451-467$

Rodgers, W. H., SPRIMger, W. \& Young, F. E. (1982). Cloning and expression of Streptomyces fradiae neomycin resistance gene in Escherichia coli. Gene 18, 133-141.

Schupp, T., Toupet, C, Stalhammer-Carlemam, M. \& Meyer, J. (1983). Expression of a neomycin phosphotransferase gene from Streptomyces fradiae in Escherichia coli after interplasmic recombination. Molecular and General Genetics 189, 27-33.

SIGGENS, K. W. (1987). Molecular cloning and characterization of the beta-amylase gene from Bacillus circulans. Molecular Microbiology' 1, 86-91.

SoUTHERN, E. M. (1975). Detection of specific sequences among DNA fragments separated by agarose gel electrophoresis. Journal of Molecular Biology 98, 503517.

Stewart, G. S. A. B., Clive, S. L.-M., Jackson, G., Cassel, A. \& KUHN, J. (1986). pHG165: a pBR322 copy number derivative of pUC8 for cloning and expression. Plasmid 15, 172-181. 
Suominen, I., Karp, M., Lahde, M., Kopiot, A., Glumoff, T., MEYer, P. \& MANTSALA, P. (1987). Extracellular production of cloned $\alpha$-amylase by Escherichia coli. Gene 61, 165-176.

TORRIANI, A. (1966). Alkaline phosphatase from Escherichia coli. In Procedures in Nucleic Acid Research, pp. 224-235, Edited by G. L. Cantoni \& D. R. Davies. New York: Harper \& Row.

Vara, J., Malpartida, F., Hopwood, D. A. \& Jimenez, A (1985). Cloning and expression of a puromycin $N$-acetyltransferase gene from Streptomyces alboniger in Streptomyces lividans and Escherichia coli. Gene 33, 197-206.
Vieira, J. \& Messing, J. (1982). The pUC plasmids, an M13mp7 derived system for insertion mutagenesis and sequencing with synthetic universal primers. Gene 19, 259-268.

Virolle, M.-J., Long, C. M., Chang, S. \& BibB, M. J. (1988). Cloning, characterisation and regulation of an $\alpha$-amylase gene from Streptomyces venezuelae. Gene 74, 321-334.

Yanisch-PerRon, C., Vieira, J. \& MEsSing, J. (1985). Improved MI3 phage cloning vectors and host strains: nucleotide sequences of the M13mpl8 and pUC19 vectors. Gene 33, 103-119. 